\title{
"DIVING" INTO THE MEANINGS AND REVEALING CONCEPTIONS OF BEING A PROFESSOR IN MANAGEMENT
}

\author{
GABRIELA T. SANTOS ${ }^{1}$ \\ https://orcid.org/0000-0002-6832-8681 \\ ANIELSON B. SILVA ${ }^{1}$ \\ https://orcid.org/0000-0002-6549-9733
}

To cite this paper: Santos, G. T., \& Silva, A. B. (2019). "Diving" into the meanings and revealing conceptions of being a professor in Management. Revista de Administração Mackenzie, 20(5). doi:10.1590/1678-6971/eRAMG190144

Submission: Sept. 11, 2018. Acceptance: May 17, 2019.

1 Universidade Federal da Paraíba (UFPB), João Pessoa, PB, Brazil.

\section{(c) $\mathrm{BY}$}

This paper may be copied, distributed, displayed, transmitted or adapted if provided, in a clear and explicit way, the name of the journal, the edition, the year and the pages on which the paper was originally published, but not suggesting that RAM endorses paper reuse. This licensing term should be made explicit in cases of reuse or distribution to third parties. It is not allowed the use for commercial purposes.

Este artigo pode ser copiado, distribuído, exibido, transmitido ou adaptado desde que citados, de forma clara e explícita, o nome da revista, a edição, o ano e as páginas nas quais o artigo foi publicado originalmente, mas sem sugerir que a RAM endosse a reutilização do artigo. Esse termo de licenciamento deve ser explicitado para os casos de reutilização ou distribuição para terceiros. Não é permitido o uso para fins comerciais. 


\section{) ABSTRACT}

Purpose: The objective of this study is to identify conceptions of being a professor in Management. The theoretical reflections that have defined the understanding of the phenomenon are associated with teaching knowledge, professor training and conceptions of being a professor.

Originality/value: The results of this study reveal that conceptions of being a professor reflect the practice of teaching and the development of knowledge perceived from the field's dominant ideologies, the socioeconomic background, and the current political contexts. This study contributes to the process of professors' Management training.

Design/methodology/approach: This is a qualitative study and uses phenomenography as a method to understand, based on outcome space, the meaning of conceptions identified through interviews conducted with 20 professors working in undergraduate and graduate Management programs in Brazil for more than ten years.

Findings: The results of the data analysis allow the identification of four conceptions of being a professor: 1 . a professional who performs the job like any other; 2 . an educator who acts as a knowledge mediator; 3 . an author of educational process; and 4. an agent who transforms people and him/herself.

\section{KEYWORDS}

Conception. Management teaching. Professor training. Phenomenography. Brazil. 


\section{INTRODUCTION}

Teaching knowledge is part of the lives of all people and is present in school since childhood, influencing the training of students. By experiencing school situations, individuals form, alter and interact with different conceptions of being a professor, a result of the teaching knowledge prevailing at the time in both the institution and the society (Tardif, 2004).

To qualify as a professor in any field, it is necessary for those involved to understand the conception of being a professor (Tardif, 2004). In this paper, we use the term "professor" to represent the teaching activity in undergraduate and graduate Management programs, in which being a professor is a process of social construction, and conceptions are linked to the academic training associated with a set of knowledge (Silva \& Costa, 2014) and to a training process that involves intellectual, contextual, social, emotional, political, and moral dimensions (Costa, Sousa, \& Silva, 2014). Therefore, understanding the conception of being a professor in Management can help to comprehend the training processes of professors.

This study is an effort by researchers to understand the practice of teaching based on conceptions of it, following the presuppositions of phenomenography (Pherali, 2011). It has as its starting point the research question:

- What are the conceptions of being a professor in a Management program?

Therefore, the aim of this article is to identify conceptions of being a professor in Management programs in the Brazilian context.

Data from the Ministry of Education of Brazil (Ministério da Educação MEC), updated in 2017, indicate that there are 3,610 public and private higher education institutions (HEIs) offering Management degree programs (E-MEC, 2017), in addition to 182 graduate master's and doctoral programs recognized by the Federal Government Agency, called the Coordinating Agency for the Improvement of Higher Education (Coordenação de Aperfeiçoamento de Pessoal de Nível Superior - Capes, 2017).

This paper contributes to knowledge of the practice of teaching in Management in four dimensions. Firstly, it broadens the understanding of being a professor based on the meanings of the experiences lived by professors in their professional trajectory. Secondly, it helps students and those aspiring to become professors to understand the implications of being a professor through educational activity and its relevance in teaching 
knowledge during training. Thirdly, the paper promotes a reflection on graduate programs on the processes of professor training in the Management field and offers the opportunity to reflect on the delimitation of training itineraries in an attempt to promote advances in the debate on teaching. Finally, the results of this study may lead professors and researchers in the Management field in other countries to conduct studies to identify the conceptions of being a professor and the specificities of professor training in international contexts. Understanding academic conceptions is essential to improve educational practice (Visser-Wijnveena, Driela, Rijsta, Verloopa, \& Visserb, 2009).

This paper also corroborates some theoretical discussions that contribute to changes and reflections in the teaching and learning process, which historically are centered on the professor (Postareff, Ylanne, \& Nevgi, 2008). The main theoretical and empirical findings of several studies (Kember \& Kwan, 2000; Samuelowicz \& Bain, 2001; Wood, 2000) have revealed that the focus of the learning process should be student-oriented and provide benefits to them, to the program in which they act and to society, without simplifying these positions in a phenomenon that is complex and multifaceted (Postareff et al., 2008). This is the transformative meaning that the results offer.

Therefore, revealing conceptions about being a professor is relevant because studies highlight the relationship between the conception adopted and the orientation of the learning process (Postareff et al., 2008). In other words, professors who share superficial conceptions of being a professor tend to focus the learning process on themselves, creating gaps that interfere in the student's development, in the learning process in the course, and impact indirectly on society. Thus, individual beliefs about teaching performance determine the way in which educational demands are handled, which in turn can be detrimental to those involved in the process (Samuelowicz \& Bain, 2001).

Next, the theoretical background concerning teaching knowledge and professor training in Management and its conceptions is presented. Subsequently, we describe the methodology of the study, present the results (outcome space) and offer final considerations.

\section{THEORETICAL BACKGROUND}

The debate about teaching knowledge begins in the 1940s, from the point of view of effects and the belief that just knowing the content was 
enough to teach: "To teach is to mobilize a wide variety of knowledge, reusing it at work to adapt and transform it, through and for work" (Tardif, 2004, p. 21).

The teaching identity is based on a process that involves the trajectory, the career, and the teaching. This trajectory involves lived experiences in the undergraduate and graduate programs as a student, and other activities not related to the teaching performance. The career refers to the expectations of being a professor developed mainly at the beginning of the teaching role. Finally, the teaching highlights the activities related to the performance of teaching, the lived relationships and the construction of an image of oneself and for others (Lima, 2018).

In this sense, teaching knowledge must be understood from a broad and integrative perspective involving questions of identity, experiences, professional trajectory and relationships with students, colleagues and those involved in the education process. A professor's career involves, according to Janasz and Sullivan (2004), a competence-based view related to three forms of knowledge or career competence: 1. people's beliefs and identities (knowing why); 2. knowledge and skills (knowing how); and 3. network or relationships (knowing who).

In this process, practical knowledge is essential as it constitutes a shared repertoire of actions, created and recreated by practical experiences lived in the complex dynamics of social interactions and their diverse contextual, cultural and symbolic conceptions, which results in the conceptions originating from the negotiation between the subject and the community, which represents a situated learning process (Tardif, 2004; Wenger, 1998).

In Brazil, such initiatives arose from political and social movements culminating in the promulgation in 1996 of the National Educational Bases and Guidelines Law (Lei de Diretrizes e Bases da Educação), the National Basic Education Development Fund, the Assessment Systems for Educational Programs, and the National Curricular Parameters (Borges \& Tardif, 2001). The issue is also influenced by various fields, such as social sciences, psychology, sociology, and education, which causes convergence and dissent. Since the 1990s, higher education in Brazil has experienced a rapid expansion, as a consequence of government educational policies (Strauss \& Borenstein, 2015), and that has affected the teaching and learning process.

Teaching knowledge has come to guide understanding of the teaching activity and is related to its applicability in day-to-day activities. Thus, the actions, activities, and practices of teaching can be understood by the set of 
knowledge articulated around their utility. This process involves "deliberating, judging and deciding about the action to be taken, the gesture to be made or the word to be pronounced before, during and after the pedagogical act" (Gauthier, Martineau, Desbiens, Malo, \& Simard, 1998, p. 331).

In graduate programs, teaching knowledge is developed by dealing with classroom needs, technologies, individual characteristics and the norms/ rules dictated by higher education institutions (Isaia \& Maciel, 2011). In Management, teaching knowledge also involves power relationships, emotional and professional experiences (Villardi, 2004), and the ability to develop teaching skills.

Studies have been conducted in graduate Management programs to define training itineraries based on theoretical, epistemological and methodological knowledge, teaching practice and writing production (Silva \& Costa, 2014; Kamler \& Thomson, 2006), and reflecting on postgraduate training in Management with the proposition of a guidance model (Costa et al., 2014).

Therefore, there is a need to initiate professors' training processes through the conception of what it is to be a professor. This is directly influenced by the pattern adopted in professional practices (Åkerlind, 2004). It is the relationship between knowledge and the representation of social practices, explains Van Dijk (2003), showing that each person analyses, interprets and recognizes a situation based on their social relations and conceptions, the values in which teaching knowledge is inscribed and the powers conferred upon it.

Teaching is a craft made of knowledge, and this craft is developed through the combination of different knowledge and the ability to cope with the actual demands of the development of teaching (Gauthier et al., 1998). Content knowledge is embedded in curricular knowledge, as well as knowledge in the field in which the professor is qualified, and is linked with both experiential knowledge and knowledge of pedagogical action (Tardif, 2004). Teaching knowledge has implications for professors' training, as it involves professional, personal, and institutional dimensions. Figure 2.1 illustrates the complexity of being a professor and the interaction with teaching knowledge. 


\section{(Figure 2.1)}

\section{TEACHING KNOWLEDGE IN PROFESSOR TRAINING}

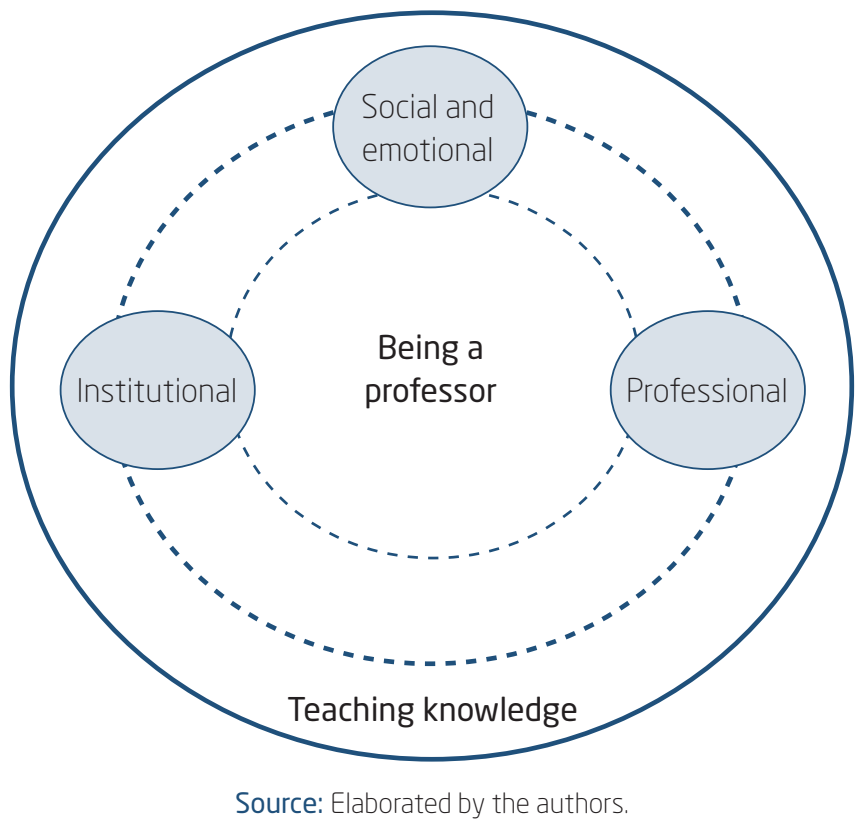

The social and emotional dimensions come from a more subjective logic involving personal behaviors, feelings, emotions, needs and expectations (Tardif, 2004; Zuber-Skerritt, 1987). The professional dimension involves the experiences acquired throughout life, particularly those related to the process of learning in several environments: at school, at the university, in mentoring activities, at work, by learning or teaching something new, and so on (Gardner \& Barnes, 2014; Storey \& Richard, 2013; Tardif, 2004). The institutional dimension reveals the importance of professors' training processes, particularly in graduate programs, which will help in training to become a professor (Åkerlind, 2004; Silva \& Costa, 2014; Storey \& Richard, 2013).

The relations between the three dimensions transform and alter teaching knowledge, producing and reassigning meanings because it occurs through different roles and different representations over time, which Tardif (2004) names existential, social and pragmatic. These relationships are temporary because they undergo changes during the various phases (exploration, stabilization, and consolidation) of the professor's career; the dimensions assist professors in developing of the profession him/herself and from preprofessional experiences (Tardif, 2004). 
In this article, we adopt the approach from the field of sociology of work, which involves a conception of being a professor associated with behavioral patterns, social interaction and personal experiences. We start from the epistemology of practice to understand that teaching knowledge is social and that experience and socialization at work assist in understanding this field.

It is in this complexity of being a professor that conceptions of it acquire different meanings. Conception refers to a way of experiencing a phenomenon and interpreting it. One conception refers to a mode of living a phenomenon and interpreting it (Åkerlind, 2004).

Therefore, conceptions about teaching may be more closely associated with common sense, providing a more superficial meaning (Ecco \& Bombardelli, 2011), or may involve complex elements in the daily routine to cope with different activities (Costa, Cardoso, \& Costa, 2012), perhaps indicating a deeper meaning.

Åkerlind (2004) conducted a phenomenographic study with 28 undergraduate professors and identified four categories that represent different ways of understanding the experience or the career of being an undergraduate professor. The first category of being a professor is associated with transmitting knowledge, disregarding the studentss role in the learning process. The second involves an experience focused on student relationships. Although this category is also centered on the professor, it incorporates the need to motivate and satisfy the student. The third category encompasses the experience of engaging with learners who are an important part of the learning process and seek self-motivation, decreasing the focus on the professor. The last category is associated with the studentcentered learning experience and with the goal of developing critical citizens, with transformative potential for the professor and for the world in which he/she lives.

In Kember and Kwan's (2000) study, the professor-centered conceptions of teaching that emerged were "teaching as transmission of knowledge", and centered on the student as "teaching as learning facilitation", which involves students' needs in the process, assisting them in the development of autonomy. Another study (Samuelowicz \& Bain, 2001) revealed that professors' beliefs about teaching are also centered on the professor (providing and facilitating discussions, revealing professor and student roles, as well as relationships between them) and student-oriented (helping students to develop competences), as well as on the complexity of defining boundaries and complex changes. 
Another phenomenographic study by Wood (2000) presents the conceptions of teaching revealed by graduate students in the United Kingdom. These conceptions are: 1 . focused on the agent of teaching (professor); 2. focused on the act of teaching, in which the student is perceived in the process and there is a relationship of reciprocity different from the previous conception; and 3. focused on the subject of teaching and oriented to students' understanding about the content and educational experiences. This conception promotes meaningful learning and the professor is also an apprentice.

These phenomenographic studies highlight that superficial conceptions are related to the professor (role, activities, relationship). Nevertheless, the deeper conceptions of being a professor are associated to student-oriented learning.

On the other hand, a central feature point out by Postareff et al. (2008) is that experience, in terms of years of performance, does not promote more student-oriented teaching in the professor, but an ability to reflect on the conception of teaching that shares and strengthens. Evidence indicates that processes related to the pedagogical formation of the professor help in the development of the capacity for reflection (Wood, 2000) and more slowly lead to change in the conceptions of teaching (Postareff et al., 2008).

Therefore, conceptions of being a professor: 1. involve those able to articulate technical and pedagogical competence and humanistic training (Costa et al., 2012); 2. relate to a vocational ability in the professor's full professional action (Ecco \& Bombardelli, 2011); and 3. include the teaching conception in social relations through the education offered to society (Park \& Braxton, 2013). Thus, it is possible to understand that conceptions can be more economic, when relating to financial aspects, more social, involving welfare issues, or more visceral, marked by emotions and transformation processes in the meaning perspectives.

These conceptions may be associated with the training processes lived by students at the postgraduate level (Åkerlind, 2011), as this learning environment may allow the living of meaningful experiences (Kisfalvi \& Oliver, 2015), such as mentorships (Gardner \& Barnes, 2014; Janasz \& Sullivan, 2004; Johnston, Keller, \& Linnhoff, 2014) or teaching practices (Muzaffar \& Malik, 2012), participation in research groups (López-Yáñez \& Altopiedi, 2015), supervising academic processes (Acker, Hill, \& Black, 1994; Costa et al., 2014; Doloriert, Sambrook, \& Stewart, 2012), as well as disconnected, transitional and connected conceptions of teaching and researching (Light \& Calkins, 2015). 
Therefore, institutions offering master's and doctoral programs in Management may influence the formation of professor conceptions through their formal and informal processes of learning, leading the agents involved in training to define or rethink the itineraries for professor training in graduate programs (Silva \& Costa, 2014) to qualify conceptions of being a professor for graduate students.

\section{RESEARCH METHOD}

A study with a phenomenographic design aims to investigate variation in the underlying meaning of, or ways of experiencing or understanding, a phenomenon (Åkerlind, 2004; Sandberg, 2000) as perceived by the people who experience it (Feldon \& Tofel-Grehl, 2018) and constituted as an internal relationship between the subject and the world (Wood, 2000). It is, therefore, a way, not only to reveal different senses of the phenomenon under investigation but also to understand the dynamics of the variation (Feldon \& Tofel-Grehl, 2018) in understanding the same phenomenon (Åkerlind, 2005a).

Empirically, phenomenography sets out to "explore ideas, beliefs and the nature of knowledge through the descriptions of conceptions" (Pherali, 2011 , p. 17) or to identify "key dimensions of variation and common themes of expanding awareness running through the categories of description" (Åkerlind, 2005b, p. 145).

Conceptions "are dependent both on human activity and the world or reality external to any individual" (Svensson, 1997, p. 165) and are presented in a hierarchy, from the most superficial to the deepest, characterizing the "space" of variation and levels of understanding of the phenomenon (Åkerlind, 2004). They are abstract representations of how people understand the world in which they live and these serve to determine forms of interaction (Kember \& Kwan, 2000).

The methodological structure of phenomenography involves the configuration of subjects' conceptions based on hierarchical interactions among themselves and are influenced by physical and social factors that make up the phenomenon. These interactions can occur dynamically between conceptions so that one conception sustains another in its position (Feldon \& Tofel-Grehl, 2018). The "outcome space" presents the different views of the phenomenon and how its variation occurs based on the relationships between the different views (Åkerlind, 2004, 2005a), and also indicates their interrelationships (Cherman \& Rocha-Pinto, 2016). 
The research process using phenomenography involves accessing the data, reflecting on the analyses and, according to the theory, indicating which conceptions are involved with the phenomenon studied. In other words, it indicates the relationship between theory, action, and reflection pointed out by Wood (2000). The outcome space represents the complete description of the phenomenon that was possible from the collective thought (Cherman \& Rocha-Pinto, 2016).

To achieve the objective proposed in this study, the methodological trajectory of the research was in six stages. The first aimed to understand the problem in question and become familiar with the subject of study in order to identify the method that best suits its specifications. Thus, qualitative (Merriam, 2009) and phenomenographical (Marton, 1981; Pherali, 2011) approaches were chosen.

Characterization of the phenomenographical study is the second stage in the methodological trajectory. This comes from the assumption that reality is socially constructed; therefore, an understanding was sought concerning how professors interpret their experiences and construct their worlds, and what meanings are attributed to the experience of being a professor in undergraduate and graduate Management programs.

Phenomenography was chosen because, in addition to being directly related to the educational environment (Pherali, 2011), it promotes, through the outcome space, a broad and realistic perception of the phenomenon researched with identified concepts, from the most superficial to the deepest (Renstrom, Andersson, \& Marton, 1990) according to the user's perception (Shenton \& Hayter, 2006). The conceptions, therefore, represent the descriptive units of phenomenography which can be structured into four or five categories resulting from approximately 20 interviews (Tight, 2016), organized according to the complexity of the different variations presented (Åkerlind, 2011).

The third stage in the methodological trajectory involves defining the data collection instrument and the script to be followed. The interview was best suited to encourage interviewees to talk about their experiences through dialogue with the purpose of collecting more complete perceptions of the phenomenon researched (Sandberg, 2000). In this study, we used additional questions such as "What does it mean to you?" or "Could you give a concrete example?". These questions were also indicated in the phenomenographic interview questions proposed by Åkerlind (2005a).

The questions were pre-defined to provide flexibility, such as changing the order of the questions to allow for the dynamic of the interview process. 
The script was defined based on the trilogy of phenomenography-perception, thought, and action - which can describe the conception of this phenomenon (Cherman \& Rocha-Pinto, 2016).

(Figure 3.1)

TRILOGY OF PHENOMENOGRAPHY IN THE SCRIPT

\begin{tabular}{lll}
\multicolumn{1}{c}{ Trilogy } & \multicolumn{1}{c}{ Meanings } & \multicolumn{1}{c}{ Script } \\
\hline Perception & Seizes (what?) & What is it to be a professor? \\
\hline Thought & Meaning (how?) & How did you learn to be a professor? \\
\hline Action & Behavior (why?) & $\begin{array}{l}\text { Tell us about your teaching experiences. Which were the } \\
\text { most significant? Why? }\end{array}$ \\
\hline
\end{tabular}

Source: Elaborated by the authors.

From the assumption that a conception is the junction of what is conceived and how it is conceived - perception, thought and action (Sandberg, 2000) -, the trilogy represents, according to Marton (1981, p. 180), the phenomenographic approach that is to "describe, analyze and understand experiences". A description is perception, analysis, thought and action in search of the understanding of experience. The different understandings are carefully described and shape the description categories (Marton, 1981) "that contain the main parts of the conceptualized phenomenon in a holistic appearance" (Pherali, 2011, p. 18).

This study was conducted with 20 professors working in graduate Management programs in Brazil, in public institutions (13) and private institutions (7). The professors interviewed had PhDs in the areas of Management (14), Education (1), Economics (1), Pedagogy (1), Engineering (1), Philosophy (1), and Social Work (1). Ten persons interviewed had teaching experience between 21 and 30 years, seven had between 10 and 20 years of practice, and three had between 31 and 40 years of teaching experience.

After the interviews, the fifth stage involved transcribing and codifying the data. The professors' statements were codified using the letter P (professor), which means professor, followed by the number of the interview and the number of the excerpt associated with a conception of being a professor that was extracted for analysis. Following the transcription of the data, it was read and analyzed carefully to be transformed into coded protocols to identify the conceptions. 
The sixth and last stage involves the identification of conceptions and the writing of the phenomenographical text which characterizes the outcome space. The process was guided by objectivity, meaning and complexity levels, for phenomenography conceptions are presented from the most superficial, objective and concrete to the deeper meanings.

Establishing boundaries between conceptions was not an easy process, but it was guided by the links between the meanings that were revealed in the data analysis. As pointed out by Visser-Wijnveena et al. (2009), academic conceptions are not easy to identify because they are contextualized and there is a lack of willingness to speak about them.

In addition, it is important to note that the accounts are not rigid, and the same professor may indicate meanings relating to more than one conception. The statements are related to the phenomenon and not to the subject. In this way, it is possible that the same participant can express more than one conception. This indicates the general and specific (broad and singular) character that conceptions assume. Therefore, they are placed in mixed models that encompass aspects of both ideographic and nomothetic traditions. In this sense, phenomenography is a method that occupies a singular space with an application, especially in mixed designs (Feldon \& Tofel-Grehl, 2018).

In summary, most professors who participated in the research present a conception that goes beyond content, that is, to educate the attitude towards life and of its values. In some cases, from the experiences reported, they already have a deeper conception, which reveals the existence of a superficialdeep continuum of being a professor in Management, characterized by professors' lived experiences throughout their lives and professional trajectories. The conceptions form a continuum because they are presented in a way such that the complexity of the phenomenon increases and involves different levels of understanding of the phenomenon in a collective network (Cherman \& Rocha-Pinto, 2016).

A specificity linked to the identification of conceptions is indicated in the title of this article, with the word "diving" meaning a process of immersion in the phenomenon from a more superficial to a deeper level in relation to the meaning of being a professor in Management. Figure 3.2 describes the trajectory of this study's phenomenographical nature. 
(Figure 3.2)

\section{STUDY TRAJECTORY}

$1^{\text {st }}$ stage

Delimitation of the study problem (being a professor

in Management) and the methodological approach

(qualitative)

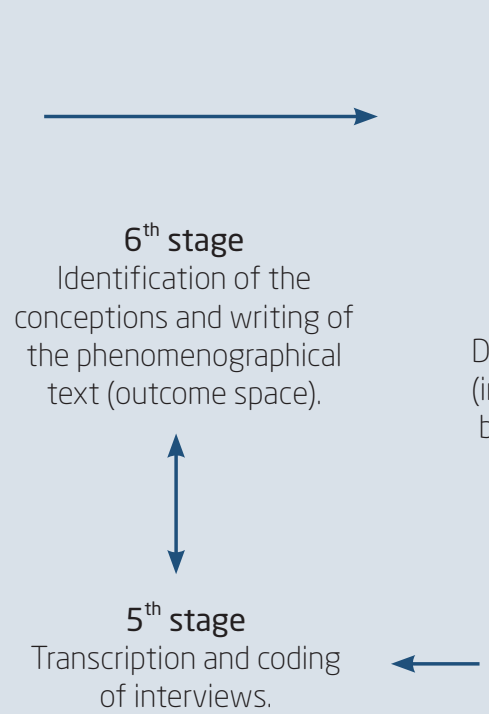

$2^{\text {nd }}$ stage

Choice of

research strategy

(phenomenography).

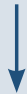

$3^{\text {rd }}$ stage

Data collection strategy (interview), with a script based on the trilogy of phenomenography.

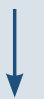

$4^{\text {th }}$ stage

Data collection (interviews).

Source: Elaborated by the authors.

Figure 3.2 shows the study trajectory, starting in the fifth stage and assuming a bidirectional perspective, as the process of identifying a conception and constructing the phenomenographical text demands the immersion and reflexivity of the researchers in the coded and categorized data. To guarantee the validity and reliability of the method, the process of identifying conceptions was initially carried out by one of the researchers; a second researcher subsequently carried out a new analysis of the established conceptions to validate them and delimit a hierarchical process in the form of a continuum, from the most superficial to the most profound conceptions. The designation of each conception in the outcome space was based on respondents' sentences considered most representative of the conception's meaning. The next section of this study presents the findings through the outcome space.

The four conceptions of being a professor in Management identified in this study characterize the outcome space and are presented below according 
to their depth level and following the guidelines of the phenomenographical method.

\section{1 "To be a professor is to have a job like any other" (P15.1)}

This conception of being a professor in Management was observed as the most superficial among those presented in the phenomenographical outcome space and it is, therefore, the first to be analyzed. By positioning teaching as "a job like any other" (P15.1), the professor explains that it took time to understand this. He initially believed that he could change something, but over time, he faced resistance from institutions, colleagues, and students, which led him to give up the will to change.

There comes a time when we conclude "I'm not that"; we become disillusioned, go through many places that do not understand teaching, and in the end, you realize that teaching is a job. I get paid, I do the best I can, and I have the awareness that I did the best. Maybe I can act as a change agent; if that happens, great, but I'd rather not to think about it (P15.1).

It is observed in this category of description that environmental factors experienced in relationships with others were enough for the person to incorporate a feeling of little utility in their teaching practice. This is a conception that involves a sense of disappointment when evidencing the existence of expectations different from reality. Therefore, the answers or results of the teaching and learning process are transferred to the students.

I've been able to believe in teaching. Today, I don't think teaching makes sense; I don't trust in the transmission of knowledge; today, I think the professor has to use theoretical knowledge, which he acquired from practical experience, and offer it to the student, but it is the student who has to make the effort, and as a professor, you have to facilitate this process (P11.1).

These accounts emphasize conceptions of being a professor that present meanings of frustration in relation to the teaching work resulting from a conception the subject had before, perhaps at the beginning of their career, and that over time when facing challenges and difficulties, gained other contours. Thus, because they have been in educational practice for some 
time, in the consolidation phase, they experienced professional relations, the evolution of the profession and personal development that reaffirmed the meaning of being a professor (Tardif, 2004), making them frustrated and disillusioned, aspects that characterize what this conception represents.

Being a professor involves experiences related to expectations of the career, self-image and relationships lived in the professional environment. Thus, this conception is also associated with frustration in teaching (Åkerlind, 2004). The subjects spoke openly of their lived experiences, highlighting context, people, and situations that mark the reflections pointed out (Lima, 2018).

The internal factors perceived in the reports that contributed to this conception involve the career expectation, which was higher than the reality; changes in attitude in the face of challenges and conflicts, as the subjects opted not to oppose them any longer; and barriers to change, as they needed to adapt to new times and were frustrated by not being able to respond. Environmental changes, student styles and the use of new technologies that have changed the professor-student relationship were other factors related to the context of the professor's performance and conflict with peers and teaching institutions.

This conception is centered on the professor, around their qualifications and lived experiences in their career, disregarding others in the learning process. According to Åkerlind (2008), this is an unsophisticated and superficial conception of the teaching practice, as it only emphasizes the parts of life and situations that impact on professional performance.

Such findings reveal a conception that focuses on the agent of the teaching (Wood, 2000), in the act of teaching as knowledge transmission (Kember \& Kwan, 2000) or teaching as a transmission experience (Åkerlind, 2004). These professor-centered conceptions indicate a professional performance associated with fulfilling the role of transmitting structured knowledge without considering other agents in the learning process. Åkerlind (2004) points out the frustration of teaching in the face of student performance or the inability to receive feedback as factors connected to this conception.

One aspect that contributed to the meaning of this conception was the lack of, or little, vocation for teaching, associated with poor experiential training. It is necessary to reflect on the process of professor-researcher training around vocation with the purpose of contributing to the quality of teaching and advancement in education. The doctoral dissertation, for example, is for some part of a process of acquiring deeper knowledge on a theme with advancement, innovation, rigor, and implications. For others, 
the doctoral dissertation only constitutes a prerequisite for obtaining a doctoral degree, which results in dissertations that contribute little or nothing to the advancement of knowledge and, in practice, this leads to the "disillusionment" that characterizes this conception. According to Akerlind (2008), this less sophisticated conception is regarded not so much as wrong, but as incomplete, characterizing the need for a conceptual expansion on the meaning of being a professor associated with more sophisticated conceptions.

\section{2 "To be a professor is to be a facilitator of knowledge" (P13.1)}

The second conception of being a professor is associated with a technical dimension of the teaching practice. In this conception, the subjects associate being a professor with being a person who "facilitates learning" (P13.1), who has the ability to "form and inform" (P1.1) and, thus, enables the "production of meanings" (P1.1). The professor is a professional helping other future professionals, indicating paths and encouraging research by establishing relationships between types of technical Management knowledge. The professor is someone who contributes "to the career of the student" (P7.1) through the reflection of information contextualized in learning.

To be a professor is to train students on the basis of science as well as to practice an honest, objective practice that improves business and society. This is my thinking of what it is to be a professor, to pass this information on to young people to train good professionals for both practice and academia (P1.1).

To be a professor is to be a facilitator of knowledge; it is to be a mediator between a historically constructed knowledge and an individual who is coming into contact with an educational experience (P13.1).

Teaching knowledge is the result of the interrelationship between subject, professor and knowledge, beyond the context, in this case, of graduate Management education. In this conception, the technical nature of the training professor dominates. The emphasis is on the ability to articulate information in the area of knowledge required to train the student and the professional capable of performing such activities. There is, therefore, a utilitarian sense in the prescription of administrative functions, 
through a functionalist and subdivided reasoning. The problem is not the promotion of this knowledge (managerialist ideology) in the learning process, but rather its exclusive use in the training of the administrator (Friga, Bettis, \& Sullivan, 2003).

This category of description presents similarities with the results of the studies by Åkerlind (2008) and Wood (2000), whose conception is professorcentered, but is also concerned with issues involving students, such as the development of students' problem solving and practical skills. There is a reciprocity between student and professor in this conception, which is more associated with technical issues that facilitate teaching.

It is possible to observe the influence of the historical, economic and political context in which knowledge was made in the Management field in the technical conception of being a professor, which means training good professionals with a scientific base and oriented towards practice and academia, revealing that being a professor also helps in the training of future Management professors, although the undergraduate degree program in Management does not have that mission. Students who choose to follow a teaching career can replicate the experiences lived by understanding that this conception of being a professor is correct.

The dimension is important, but it has limitations in teaching performance by conceiving a technicist teaching action guided by expertise. In the following account, the professor describes the meaning of being an educator as being the one who leads the student to reflect on information, which reinforces the technicist nature of this conception of training, information and transmission of knowledge.

It is being an educator, it is who trains and informs, so he must have something to inform, must have an expertise that he shares with the students. And he should allow reflection on that information. So, I think that the professor is rather a knowledge transmitter. He is an educator, and as an educator, he has this role of contextualizing the information for the student to reflect on. And he should allow reflection on that information (P17.1).

In the discourses of professors linked to this conception, the existence of internal factors related to the professors' training in their school life that may have contributed to the simple reproduction of practices, and not their questioning, is observed, and the professors' personality traits associated with conformism and lack of initiative. External factors may be associated 
with certain areas/training programs which do not encourage continued reflection on the process through reflective, experiential and transformative experiences.

Some studies show that doctoral training is more directed towards the training of researchers than of professors (Akerlind, 2011; Balkin \& Mello, 2012; Park \& Braxton, 2013), but Neumann (1992) indicates that this nexus is complex because it depends on the role of academics at both undergraduate and graduate level. So, there are three levels of the teachingresearch nexus - tangible, intangible and global, and it is important to consider: 1 . the type and purpose of the course; 2 . the ability and motivation of the student; 3 . the nature of the discipline; and 4. the level of development of the discipline.

\section{3 "To be a professor is to go far beyond content, it is to educate the attitude towards life and its values" (P19.1)}

The third conception of being a professor, unlike the other two, involves the interest of the student as an agent in the teaching process because "there's something about the interaction with people and that makes it cool" (P9.3), which goes beyond a concern with the technical activities of teaching action to be interested "genuinely in the learning of the other" (P18.1). Thus, the professor is perceived in this conception as a "transformation agent" (P2.1) who constantly challenges himself to go beyond the training of technical capabilities to "provide students with values of ethics and citizenship" (P14.1). It is a person who "likes people" (P8.2) and is "sensitive to the difference" (P6.2) perceived among students. It is a professor that "does not lose the student status" (P10.1, P20.1), so he is always reflecting on the experience to engage the needs of students in the learning process.

A professor is an individual who comes into contact with an educational experience, and his role there is not only to mediate between the experience that the individual already has in the classroom, what they already have and the formalized knowledge; it is to understand the specificities of the educational process: I have to understand where they come from, what they want, what their expectations are, what else helps them learn, what makes it difficult to learn and, at the same time, it is a constant process of revision of own experience (P13.1). 
Thus, teaching produces "engagement in social activities" (P12.1) and represents "achievement" (P3.2) and challenges in coping with everyday situations. Professors are people who seek an "emotional relationship with the other" (P4.1) because they understand that they are important for the mobilization of knowledge in action and that they assist in this approach. In addition, teaching in this conception represents the ability to "innovate" (P13.2) in the classroom and in the delivery of differentiated processes and products, providing new experiences to students.

Through the reports related to this conception, professors are observed to act in the logic of andragogy when they perceive the characteristics, needs and motivation of the Management student, making the learning outcomes more effective (Knowles, Holton, \& Swanson, 2011). This conception involves a logic centered on the student, understanding the impact of the professor's actions in the students. According to Akerlind (2008), this conception creates conditions to improve the learning process and increase students' motivation levels to learn. This conception reveals that "the only teaching which is valuable is, of course, that which leads to effective learning" (Brew \& Boud, 1995).

This logic was also identified in the studies discussed in the theoretical background. The third conception that emerged from Åkerlind's (2004) studies indicates a focus on the student-centered learning process with the goal of providing experiences that promote student self-motivation. The student-centered description categories of Kember and Kwan's (2000) study show that the professor is a "facilitator of learning" that promotes the development of autonomy. The results presented by Samuelowicz and Bain (2001) indicate a conception oriented towards the "development of students' competences".

The logic of this conception is that it conceives the other in the learning process by being sensitive to differences and by understanding or making the other understand the logic of the subject in their reflective training. To do this, the professor develops mechanisms of action that relate to the affective and emotional dimension in the learning process (Tardif, 2004). This occurs by means of attitudes and values that incorporate cooperation, solidarity, criticality, and creativity and imply the strengthening of relations defined by respect, affection and attention.

Authorship is critical because you are an example for the student. I construct a text justifying the discipline, first for me to find the importance of this course, and what the importance is to the student whom I will receive; I make a learning syllabus based on this; this text is not published - it is for them (P6.3). 
It is the ability to allow and encourage students to research, in life, their own profession, to learn how to develop a capacity to generate knowledge. It is to show the course of our trajectory (P20.1).

These reports reveal the importance of authorship in the learning process to ensure the commitment of both professor and student in educational activity. It is a means by which the professor can be made responsible and the author of his teaching practice in that context. Authorship is related to the ability to take on the commitment with responsibility and consistency, in addition to providing originality, uniqueness and independence (Azevedo \& Vaccaro, 2015) to build a shared and established feeling (Cunliffe, 2001). Therefore, the teaching practice is a shared process, whether by texts, the life trajectory or the ethical stance.

Internal factors - associated with the ability to reflect on experiences, question them and change their course, adapt in the face of new demands, put oneself in the place of the other and incorporate their needs and aspirations - assist in the development of this conception. It is worth emphasizing issues involving commitment, independence, and authorship in the teaching practice. External factors are related to feedback from students and colleagues over the teaching trajectory, participation in events and productions, and pressures from the environment where professors act. For London and Sessa (2006), feedback is crucial in the learning process, particularly in a group, as it assists in the processes of reflection and transformation of the perspectives of meaning.

\section{4 "To be a professor is to transform and be transformed" (P18.1)}

This conception of being a professor is the most comprehensive, complex and subjective, as it involves the professor himself and the other, featuring a transformative learning process (Cranton, 2006). It, therefore, emphasizes the feelings in the educational process, which represent much more than a job or a profession. Management teaching in this conception is "a way of life" (P5.1); it has the sense of a "mission" (P4.1) as a human being and involves the profession as a "vocation" (P3.1), in the complete "giving" (P14.1) of the being and knowledge in action.

What is teaching? The way of presenting is passion, which vibrates throughout the project, which believes, passing truths; passion is an element that contaminates. It's enough for me when the guy says: 
"I came to get a master's in Management, and the course that changed my life was yours" (P6.3).

By reflecting on their educational activities, professors report that they found a new professor and that they not only transform the other but are transformed with each new experience. "So, I say that today I am a professor, and until now, I was playing a professor" (P6.1). Being a professor is also an experiential and reflective process. Understanding being a professor in this conception is different from the last one (section 4.3), because it encompasses the student and considers that they should be involved more actively in the learning process. It relates to motive and inspires others by way of the transformation (Gonzalez, 2011) of a meaning perspective (Cranton, 2006).

Several professors reported significant experiences in their careers that led them to reflect on their behavior, such as "failure rates, interrupted communication. I had no sensitivity to understand the student; it was suffering" (P6.1); "I got a group that had had a conflict with a professor, so I gave my classes and when I got my grade the students made a fuss" (P19.3); "And I was very young, I didn't know how to accommodate" (P16.3). There were conflicts and suffering, and reflection was essential to understand new meanings of teaching (MacKeracher, 2012).

It is acting coherently with a posture of giving. It's one of the nicest and most responsible professions because a misplaced word can have a negative effect, or you can change the career path of a person. And the professor is a person who has feelings, and the student often looks at the professor as someone perfect, flawless. It's a magical profession because, with every person you meet, you can transform and be transformed; this explains a lot about what it is to be a professor (P18.1).

To another professor, "being a professor is to be a restless person, constantly changing; someone who is not satisfied by the next discovery, who realizes that they are incomplete" (P10.1). Experiences marked by suffering, trauma and overcoming the process of teaching and learning, both in oneself and in the other, are the result of the transformation process by understanding new meanings (Fetherston \& Kelly, 2007; Mezirow, 2000). This process contributes to the self-reflection capacity, emotional development, mobilization of new skills, the ability to understand the environment and even the applicability of new educational tools (Kasworm \& 
Bowles, 2012). This causes a sense of "empowerment" (P10.3) or that "nothing is lost" (P12.3), giving new meaning not only to being a professor but to being a person who interacts with others, which makes the "profession magic" (P5.1) by the ability to transform the other and oneself. It is in the questioning between worldviews and oneself that the person enhances transformative learning (Cranton, 2006).

In contrast, the professors' words also reveal a stereotype - that, for many students, the professor is a perfect being. However, professors are not perfect because they are, above all, human beings with feelings, emotions, and worldviews, susceptible to error through life like anyone else. Being a professor is also:

A matter of vocation, self-realization, and always thinking about how we can help others; it's something I like to do, and in this, there is the question of self-realization, which can contribute to my development and that of others (P3.1).

This conception interacts with that of experiential knowledge, which requires from the professor complete giving through his values, feelings, experiences and life stories. Experiential knowledge is transversal knowledge in the teaching practice because it interacts with the cognitive, instrumental and emotional dimensions and is developed by those who can reflect on their limitations and insecurities in relation to the other, integrating knowledge and being a professor (Tardif, 2004).

Understanding this conception reveals internal factors that characterize being a professor and are associated with the entry in a career in teaching (being not just a matter of opportunity, but of feeling); the notion of utility to society as a whole and not just to students; the capacity of resilience; and facing challenges. The external factors are associated with the trajectory of the school life of professors when they met someone who, through education, caused changes and, thus, led them to conceive the professor as an agent of change for society. One of the professors considers teaching "a devoted work that means teaching and learning with the other, a change of attitude, of posture before life" (P14.1).

These meanings, for professors who share this view, are so important that they become superior to material issues of work, such as conditions, wages, hours and other challenges, as shown by one of the professors: "I get paid poorly to do what I do, but I would pay to do it" (P12.3). This conception is the deepest of this study because it reveals that being a professor is a transformative process, devoted and mediated by passion and giving. 
The phenomenographic perspective is suitable to reveal the variations of the phenomenon (Franz et al., 1996) of being a professor. The first two variations revealed in this research are centered on the professor and the latter two involve the student and are more complex and meaningful (Gonzalez, 2011).

Figure 4.4.1 summarizes the conceptions, their meanings, what they represent in the teaching practice, and the internal and external factors associated with each conception.

(Figure 4.4.1)

CONCEPTIONS OF BEING A PROFESSOR OF MANAGEMENT

\begin{tabular}{|c|c|c|c|c|}
\hline \multirow{2}{*}{$\begin{array}{l}\text { Being a } \\
\text { professor }\end{array}$} & \multirow{2}{*}{$\begin{array}{l}\text { Connection } \\
\text { points }\end{array}$} & \multirow{2}{*}{$\begin{array}{l}\text { What it } \\
\text { represents }\end{array}$} & \multicolumn{2}{|c|}{ Factors } \\
\hline & & & Internal & External \\
\hline $\begin{array}{l}\text { It is being a } \\
\text { professional who } \\
\text { needs to perform } \\
\text { his activities like } \\
\text { any other job. }\end{array}$ & $\begin{array}{l}\text { Frustrated } \\
\text { conception. }\end{array}$ & $\begin{array}{l}\text { Disillusionment, } \\
\text { little vocation and } \\
\text { little utility of } \\
\text { being a teacher. }\end{array}$ & $\begin{array}{l}\text { Lack of vocation; } \\
\text { expectation in the } \\
\text { career; paralysis in } \\
\text { facing challenges } \\
\text { and conflicts; } \\
\text { barriers to change; } \\
\text { and difficulty in } \\
\text { delivering results. }\end{array}$ & $\begin{array}{l}\text { Environmental } \\
\text { changes; } \\
\text { students' styles; } \\
\text { introduction of } \\
\text { new technologies; } \\
\text { conflicts with } \\
\text { peers and with } \\
\text { the institution. }\end{array}$ \\
\hline $\begin{array}{l}\text { It is being an } \\
\text { educator who acts } \\
\text { as a facilitator and } \\
\text { mediator of } \\
\text { knowledge to train } \\
\text { professionals with } \\
\text { a scientific base } \\
\text { and guided by } \\
\text { professional } \\
\text { practice. }\end{array}$ & $\begin{array}{l}\text { More technical } \\
\text { and institutional } \\
\text { conception. }\end{array}$ & $\begin{array}{l}\text { Someone who } \\
\text { facilitates learning } \\
\text { and contributes to } \\
\text { the career of } \\
\text { others. }\end{array}$ & $\begin{array}{l}\text { Reproduction and } \\
\text { lack of } \\
\text { questioning, } \\
\text { personality traits } \\
\text { associated with } \\
\text { conformity and } \\
\text { lack of initiative. }\end{array}$ & $\begin{array}{l}\text { Management } \\
\text { areas/programs, } \\
\text { little incentive for } \\
\text { reflection. }\end{array}$ \\
\hline $\begin{array}{l}\text { It is being an } \\
\text { author of the } \\
\text { educational } \\
\text { process capable of } \\
\text { changing students } \\
\text { and their lives, } \\
\text { through emotion } \\
\text { and based on } \\
\text { social needs. }\end{array}$ & $\begin{array}{l}\text { Social and } \\
\text { emotional } \\
\text { conception. }\end{array}$ & $\begin{array}{l}\text { Engages in social } \\
\text { activities, fulfills } \\
\text { himself with the } \\
\text { change of the } \\
\text { other and } \\
\text { becomes the } \\
\text { author of his } \\
\text { teaching practice. }\end{array}$ & $\begin{array}{l}\text { Ability to reflect, } \\
\text { adapt and put } \\
\text { himself in the } \\
\text { place of the other. } \\
\text { Commitment, } \\
\text { independence, } \\
\text { and authorship in } \\
\text { teaching practice. }\end{array}$ & $\begin{array}{l}\text { Feedback, } \\
\text { participation } \\
\text { involving others in } \\
\text { the educational } \\
\text { process and } \\
\text { pressures from } \\
\text { the environment } \\
\text { where they act. }\end{array}$ \\
\hline
\end{tabular}




\section{(Figure 4.4.1 (conclusion))}

\section{CONCEPTIONS OF BEING A PROFESSOR OF MANAGEMENT}

\begin{tabular}{|c|c|c|c|c|}
\hline \multirow{2}{*}{$\begin{array}{l}\text { Being a } \\
\text { professor }\end{array}$} & \multirow{2}{*}{$\begin{array}{l}\text { Connection } \\
\text { points }\end{array}$} & \multirow{2}{*}{$\begin{array}{l}\text { What it } \\
\text { represents }\end{array}$} & \multicolumn{2}{|c|}{ Factors } \\
\hline & & & Internal & External \\
\hline $\begin{array}{l}\text { It is being a } \\
\text { transformation } \\
\text { agent of } \\
\text { conceptions, } \\
\text { meanings, } \\
\text { experiences, } \\
\text { beliefs, values, } \\
\text { and behaviors. }\end{array}$ & $\begin{array}{l}\text { Conception of } \\
\text { individual and } \\
\text { collective } \\
\text { transformation. }\end{array}$ & $\begin{array}{l}\text { Is passionate } \\
\text { about teaching, a } \\
\text { social reference, } \\
\text { acts with giving in } \\
\text { the teaching } \\
\text { practice, which is } \\
\text { vocational and } \\
\text { transformative. }\end{array}$ & $\begin{array}{l}\text { Vocation for } \\
\text { teaching, notion } \\
\text { of utility, } \\
\text { resilience and } \\
\text { coping with } \\
\text { challenges. }\end{array}$ & $\begin{array}{l}\text { People who have } \\
\text { been significant } \\
\text { throughout life } \\
\text { and that caused } \\
\text { changes and led } \\
\text { them to assign to } \\
\text { the professor a } \\
\text { status of agent of } \\
\text { change for } \\
\text { society. }\end{array}$ \\
\hline
\end{tabular}

Source: Elaborated by the authors.

The internal and external factors of Figure 4.4.1 are representations of the experiences lived by the subjects that help in understanding the conceptions described in this study. In other words, in revealing the structural relations of conceptions of being a professor, it is possible to present the social and physical factors external to the individual that assist in understanding these categories of description. This proposition is supported by the work of Feldon and Tofel-Grehl (2018).

Among the conceptions presented in Figure 4.4.1, those that are at a more superficial level indicate the "craft without knowledge and knowledge without the craft" of teaching, as it would be enough to impart knowledge, to know the content or to have experience (Gauthier et al., 1998, p. 20). Deeper conceptions incorporate social needs, the dimension of emotions, and the transformation in the vocation of being a professor, in which the professor represents "more than someone who teaches" (Zabalza, 2013, p. 13), but is a person able to follow an educational process, assisting in the development of the other and of himself.

The results of this study are corroborated by the work of VisserWijnveena et al. (2009), in which conceptions of teaching in a university are presented in a continuum that starts with only the transmission of knowledge and moves to contributing to changing beliefs and concepts. Åkerlind (2008) highlights that an alternative path for improving teaching and learning processes is developing the concept of the teaching practice even before studying the methods and skills involved in teaching. 


\section{FINAL CONSIDERATIONS}

This article has revealed conceptions of being a professor in the eyes of professors of Management working in graduate and postgraduate education in Brazil, from the characterization of the phenomenographical outcome space. It is observed that the conceptions of being a professor are constituted through personal, professional and institutional dimensions, and through knowledge conceived from the dominant ideologies of the field, the economic and socio-political context, and are established over time. Thus, the teaching practice is a complex and dynamic process, mediated by social relationships and interactions that sustain and direct new paths.

In addition to revealing conceptions of being a professor in the Management field as a continuum, the results of this study may contribute to the training of future professors in the context of master's and doctoral postgraduate programs, helping them to reflect on what it means to be a professor.

Discussing being a professor in the field requires a reflection on training, which consists, on one hand, of a concern with excessive prescriptive knowledge which can influence the creation of knowledge in future professors and, on the other hand, of the socio-emotional and transformative experiences of the teaching practice.

This study shows that conceptions of being a professor in the context of Management are influenced by the development of the field, particularly in the Brazilian context, in terms of a more technical conception, but it is necessary to incorporate social interest as a relevant dimension in professional training, and it is up to the professor to help students understand, in addition to their contribution to the organizational context, their role as agents of social transformation.

The deepest conceptions of being a professor are linked to principles and values that involve social and emotional relationships in the professorstudent interaction and that should mediate the conception of the professional action. In addition, the deepest meaning of being a professor is observed to be associated with a transformation in the meaning perspectives, which, in addition to transforming the professor, must also be able to transform the students, incorporating a transformative learning process (Kasworm \& Bowles, 2012).

This study, in addition to theoretical and empirical contributions on the meaning of being a professor in Management, has practical implications for 
professor training. It is, therefore, recommended that postgraduate Management programs, in their processes of developing teaching practice knowledge, highlight the reflections on being a professor in the technical-professional, social and emotional and institutional dimensions, for it is up to each program to establish within its curricular framework the elements that guide the processes of professor training. Such processes can be guided by experiential and transformative learning so that future professors can construct their own authorship in relation to their professional practice. This reflection to develop deeper understanding below graduate level is rarely stimulated ( $\AA$ kerlind, 2008) and is another contribution of this study to the field of teacher formation.

It is noteworthy that this study reveals the conceptions of professors working in graduate and postgraduate programs in Brazil. Conducting studies in other countries may help broaden the understanding on teaching knowledge and practice and reveal peculiar conceptions linked not only to the specificities of professor training but also to the cultural and social traditions that reveal the complex nature and dynamics of professor training and the professional practice context.

\section{"MERGULHANDO" NOS SIGNIFICADOS E REVELANDO CONCEPÇÕES DO SER PROFESSOR NA ADMINISTRAÇÃO}

\section{RESUMO}

Objetivo: O objetivo deste estudo é identificar as concepções do ser professor em Administração. As reflexões teóricas que definiram a compreensão do fenômeno estão associadas ao conhecimento docente, à formação de professores e às concepções do ser professor.

Originalidade/valor: Os resultados deste estudo revelam que as concepções do ser professor refletem sobre a prática docente e no desenvolvimento dos saberes concebidos a partir das ideologias dominantes do campo, dos contextos socioeconômicos e dos contextos políticos atuais. Este estudo contribui para o processo de formação do professor em Administração.

Design/metodologia/abordagem: Trata-se de um estudo qualitativo que utiliza a fenomenografia como método para compreender, a partir do 
espaço de resultados, o significado das concepções identificadas por meio de entrevistas realizadas com 20 professores atuantes na pós-graduação de Administração de programas no Brasil por mais de dez anos. Resultados: Os resultados da análise dos dados permitiram a identificação de quatro concepções do ser professor: 1. um profissional que realiza o trabalho como qualquer outro; 2. um educador que atua como mediador do conhecimento; 3 . um autor de processo educacional; e 4. um agente que transforma as pessoas e a si mesmo.

\section{PALAVRAS-CHAVE}

Concepções. Ensino de Administração. Formação de professores. Fenomenografia. Brasil.

\section{$\int$ REFERENCES}

Acker, S., Hill, T., \& Black, E. (1994). Thesis supervision in the social sciences: Managed or negotiated? Higher Education, 28, 483-498. doi:10.1007/bf01383939

Åkerlind, G. S. A. (2004). A new dimension to understanding university teaching. Teaching in Higher Education, 9(3), 363-375. doi:10.1080/135625 1042000216679

Åkerlind, G. S. (2005a). Learning about phenomenography: Interviewing, data analysis and the qualitative research paradigm. In J. A. Bowden \& P. Green (Eds.), Doing developmental phenomenography (pp. 63-73). Melbourne, Australia: RMIT Press.

Åkerlind, G. S. (2005b). Ways of experiencing being a university researcher. In J. A. Bowden \& P. Green (Eds.), Doing developmental phenomenography (pp. 145-155). Melbourne, Australia: RMIT Press.

Åkerlind, G. S. A. (2008). A phenomenographic approach to developing academics' understanding of the nature of teaching and learning. Teaching in Higher Education, 13(6), 633-644. doi:10.1080/13562510802452350

Åkerlind, G. S. (2011). Separating the "teaching" from the "academic": Possible unintended consequences. Teaching in Higher Education, 16(2), 183-195. doi:10.1080/13562517.2010.507310 
Azevedo, D., \& Vaccaro, G. L. R. (2015, Apr.). Authorship as a practical collective accomplishment. Paper presented at the OLKC Conference, Milan, Italy.

Balkin, D. B., \& Mello, J. (2012). Facilitating and creating synergies between teaching and research: The role of the academic administrator. Journal of Management Education, 36(4), 471-494. doi:10.1177/1052562911420372

Borges, C. M. F., \& Tardif, M. A. (2001). Dossiê temático da revista educação \& sociedade. Educação E Sociedade, 74. doi:10.1590/S0101-733020010001 00002

Brew, A., \& Boud, D. (1995). Teaching and research: Establishing the vital link with learning. Higher Education, 29, 261-273. doi:10.1007/bf01384493

Cherman, A., \& Rocha-Pinto, S. R. (2016). Valoração do conhecimento nas organizações e sua incorporação nas práticas e rotinas organizacionais. Revista Brasileira de Gestão de Negócios, 18(61), 416-435. doi:10.17771/ pucrio.acad.23561

Coordenação de Aperfeiçoamento de Pessoal de Nível Superior (2017). Avaliação quadrienal em números. Recuperado de https://sucupira.capes. gov. br/sucupira/

Costa, F. J., Sousa, S. C. T., \& Silva, A. B. (2014). Um modelo para o processo de orientação na pós-graduação. Revista Brasileira de Pós-Graduação, 11 (25), 823-852. doi:10.21713/2358-2332.2014.v11.638

Costa, N. M. S. C., Cardoso, C. G. L. V., \& Costa, D. C. (2012). Um modelo para o processo de orientação na pós-graduação. Revista Brasileira de Educação Médica, 36 (4), 499-505. doi:10.1590/s0100-55022012000600008

Cranton, P. (2006). Understanding and promoting transformative learning: A guide for educators of adults (2nd ed.). San Francisco, CA: Jossey-Bass Publishers.

Cunliffe, A. L. (2001). Managers as practical authors: Reconstructing our understanding of management practice. Journal of Management Studies, 28(3), 351-371. doi:10.1111/1467-6486.00240

Doloriert, C., Sambrook, S., \& Stewart, J. (2012). Power and emotion in doctoral supervision: Implications for HRD. European Journal of Training and Development, 36(7), 732-750. doi:10.1108/03090591211255566

Ecco, I., \& Bombardelli, A. P. (2011). Being a teacher: Conceptions present in a teacher training course. Perspectiva, 35(132), 147-158.

Feldon, D. F., \& Tofel-Grehl, C. (2018). Phenomenography as a foundation for mixed models research. American Behavioral Scientist, 62 (7), 887-899. doi:10.1177/0002764218772640 
Fetherston, B., \& Kelly, R. (2007). Conflict resolution and transformative pedagogy: A grounded theory research project on learning in higher education. Journal of Transformative Education, 5, 262-285. doi:10.1177/1541 344607308899

Franz, J., Ferreira, L., Loh, H., Pendergast, D., Service, M., Stormont, D., Taylor, L., Thambiratnam, D., \& Williamson, B. (1996). Students' and lecturers' conceptions of learning in context: An interdisciplinary study. Teaching in Higher Education, 1 (3), 325-329. doi:10.1080/1356251960010304

Friga, P. N., Bettis, R. A., \& Sullivan, R. S. (2003). Changes in graduate management education and new business school strategies for the $21 \mathrm{st}$ century. Academy of Management Learning and Education, 2(3), 233-249. doi:10.5465/amle.2003.10932123

Gardner, S. K., \& Barnes, B. J. (2014). Advising \& mentoring doctoral students: A handbook. Lexington: CreateSpace Independent Publishing Platform.

Gauthier, C., Martineau, S., Desbiens, J.-F., Malo, A., \& Simard, D. (1998). For a theory of pedagogy: Contemporary research on teacher knowledge. Ijuí: Unijuí.

Gonzalez, C. (2011). Extending research on "conceptions of teaching": Commonalities and differences in recent investigations. Teaching in Higher Education, 16(1), 65-80. doi:10.1080/13562517.2010.507302

Isaia, S. M. A., \& Maciel, A. M. A. I. (2011). Comunidades de práticas pedagógicas universitárias em ação: Construindo a aprendizagem docente. Imagem da Educação, 1 (1), 37-47. doi:10.4025/imagenseduc.v1i1.12349

Janasz, S. C., \& Sullivan, S. E. (2004). Multiple mentoring in academe: Developing the professorial network. Journal of Vocational Behavior, 64, 263-283. doi:10.5465/apbpp.2002.7516573

Johnston, T. C., Keller, R. H., \& Linnhoff, S. (2014). Mentoring in doctoral programs and preparedness of early career marketing educators. Academy of Educational Leadership Journal, 18(4), 15-22.

Kamler, B., \& Thomson, P. (2006). Helping doctoral students write: Pedagogies for supervision. New York: Routledge.

Kasworm, C. E., \& Bowles, T. A. (2012). Foresting transformative learning in higher education settings. In E. W. Taylor \& P. Cranton (Eds.), The handbook of transformative learning: Theory, research, and practice (pp. 388-407). San Francisco, CA: Jossey-Bass.

Kember, D., \& Kwan, K. P. (2000). Lecturers' approaches to teaching and their relationship to conceptions of good teaching. Instructional Science, 28, 469-490. doi:10.1007/978-94-010-0593-7_10 
Kisfalvi, V., \& Oliver, D. (2015). Creating and maintaining a safe space in experiential learning. Journal of Management Education, 39(6), 713-740. doi:10.1177/1052562915574724

Knowles, M. S., Holton, E., \& Swanson, R. A. (2011). The adult learner: The definitive classic in adult education and human resource management (7th ed.). Burlington, MA: Butterworth-Heinemann, Elsevier.

Light, G., \& Calkins, S. (2015). The experience of academic learning: Uneven conceptions of learning across research and teaching. Higher Education, 69, 345-359. doi:10.1007/s10734-014-9779-0

Lima, J. P. R. (2018). Ser professor: Um estudo da identidade docente na área de Ciências Contábeis (Dissertação de mestrado, Universidade de São Paulo, Ribeirão Preto, SP, Brasil). Recuperado de http://www.teses.usp.br/teses/ disponiveis/96/96133/tde-23042018-103503/pt-br.php

London, M., \& Sessa, V. I. (2006). Group feedback for continuous learning. Human Resource Development Review, 5(3), 303-329. doi:10.1177/153448 4306290226

López-Yáñez, J., \& Altopiedi, M. (2015). Evolution and social dynamics of acknowledged research groups. Higher Education, 70, 629-647. doi:10.1007/ s10734-014-9835-9

MacKeracher, D. (2012). The role of experience in transformative learning. In E. W. Taylor \& P. Cranton (Eds.), The handbook of transformative learning: Theory, research, and practice (pp. 342-354). San Francisco, CA: Jossey Bass.

Marton, F. (1981). Phenomenography. Describing conceptions of the world around us. Instructional Science, 10, 177-200. doi:10.1007/bf00132516

Merriam, S. B. (2009). Qualitative research: A guide to design and interpretation. San Francisco, CA: Jossey-Bass.

Mezirow, J. (2000). Learning to think like an adult: Core concepts of transformation theory. In J. Mezirow and associates (Eds.), Learning as transformation: Critical perspectives on a theory in progress (pp. 3-33). San Francisco, CA: Jossey-Bass.

Ministério da Educação (2017). Cadastro Nacional de Cursos e Instituições de Educação Superior Cadastro e-MEC. Recuperado de http://emec.mec. gov.br/

Muzaffar, M., \& Malik, S. Y. (2012, August). Attitude of teachers towards professional development trainings. Language in India, 12 (8), 304-322.

Neumann, R. (1992). Perceptions of the teaching-research nexus: A framework for analysis. Higher Education, 23(2), 159-171. doi:10.1007/ bf00143643 
Park, T. J., \& Braxton, J. M. (2013). Delineating scholarly types of college and university faculty members. The Journal of Higher Education, 84(3), 301-328. doi:10.1353/jhe.2013.0015

Pherali, T. J. (2011). Phenomenography as a research strategy: Researching environmental conceptions. Saarbrücken: Lambert Academic Publishing.

Postareff, L., Ylanne, L. S., \& Nevgi, A. (2008). A follow-up study of the effect of pedagogical training on teaching in higher education. Higher Education, 56(1), 29-42. doi:10.1007/s10734-007-9087-z

Renstrom, L., Andersson, B., \& Marton, F. (1990). Students' conceptions of matter. Journal of Educational Psychology, 82(3), 555-569. doi:10.1037//00 22-0663.82.3.555

Samuelowicz, K., \& Bain, J. B. (2001). Revisiting academics' beliefs about teaching and learning. Higher Education, 41, 299-325.

Sandberg, J. (2000). Understanding human competence at work: An interpretative approach. Academy of Management Journal, 43(1), 9-25. doi: $10.5465 / 1556383$

Shenton, A., \& Hayter, S. (2006). Terminology deconstructed: Phenomenographic approaches to investigating the term "information". Library \& Information Science Research, 28(4), 563-578. doi:10.1016/j.lisr.2006.10.003

Silva, A. B., \& Costa, F. J. (2014). Itinerários para o desenvolvimento da competência docente na pós-graduação stricto sensu em administração. Revista Economia \& Gestão, 14(34), 30-57.

Storey, V. A., \& Richard, M. B. (2013). Critical friends groups: Moving beyond mentoring. In V. A. Storey (Ed.), Redesigning professional education doctorates: Applications for critical friendship to the EdD (pp. 9-24). Hampshire: Palgrave Macmillan.

Strauss, L. M., \& Borenstein, D. (2015). A system dynamics model for longterm planning of the undergraduate education in Brazil. Higher Education, 69(3), 375-397. doi:10.1007/s10734-014-9781-6

Svensson, L. (1997). Theoretical foundations of phenomenography. Higher Education Research \& Development, 16(2), 159-171. doi:10.1080/072943 6970160204

Tardif, M. (2004). Los saberes del docente y su desarrollo professional. Madrid: Narcea.

Tight, M. (2016). Phenomenography: The development and application of an innovative research design in higher education research. International Journal of Social Research Methodology, 19(3), 319-338. doi:10.1080/136455 79.2015.1010284 
Van Dijk, T. (2003). The discourse-knowledge interface. In G. Weiss \& R. Wodak (Eds.), Critical discourse analysis: Theory and interdisciplinarity (pp. 85-109). Basingstoke: Palgrave.

Villardi, B. Q. (2004). Um estudo reflexivo sobre microprocessos de aprendizagem e mudança coletiva docente com a aprendizagem e mudança organizacional resultantes: Para uma gestão sustentável do desenvolvimento de docentes em instituições de educação superior privada em administração e marketing (Tese de doutorado, Pontifícia Universidade Católica do Rio de Janeiro, RJ, Brasil).

Visser-Wijnveena, G. J., Driela, J. H. V., Rijsta, R. M. V., Verloopa, N., \& Visserb, A. (2009). The relationship between academics' conceptions of knowledge, research and teaching: A metaphor study. Teaching in Higher Education, 14(6), 673-686. doi:10.1080/13562510903315340

Wenger, E. (1998). Communities of practice: Learning, meaning and identity. New York: Cambridge University Press.

Wood, K. (2000). The experience of learning to teach: Changing student teachers' ways of understanding teaching. Journal of Curriculum Studies, 32(1), 75-93. doi:10.1080/002202700182862

Zabalza, M. Z. (2013). Ser docente es más que ser enseñante. Revista de Docencia Universitaria, 11(2), 11-14. doi:10.4995/redu.2013.5563

Zuber-Skerritt, O. (1987). Helping postgraduate research students learn. Higher Education, 16(1), 75-94. doi:10.1007/bf00139249

\section{ACKNOWLEDGMENTS}

The authors thank Conselho Nacional de Desenvolvimento Científico e Tecnológico (CNPq) and Coordenação de Aperfeiçoamento de Pessoal de Nível Superior (Capes), Brazilian agencies, for the financial support to conduct this study.

\section{AUTHOR NOTES}

Gabriela T. Santos, Departamento de Ciências Sociais Aplicadas, Universidade Federal da Paraíba (UFPB); and Anielson B. Silva, Departamento de Administração, Universidade Federal da Paraíba (UFPB). 
Gabriela T. Santos is now full professor at Social Science Applied Department at Universidade Federal da Paraíba (UFPB); and Anielson B. Silva is now full professor at Management Department at Universidade Federal da Paraíba (UFPB).

Correspondence concerning this article should be addressed to Anielson B. Silva, Universidade Federal da Paraíba - Centro de Ciências Sociais Aplicadas, campus universitário s/n, Castelo Branco, João Pessoa, Paraíba, Brazil, CEP 58051-090.

E-mail: anielson@uol.com.br

\section{EDITORIAL BOARD}

Editors-in-chief

Janette Brunstein

Silvia Marcia Russi de Domênico

\section{Associated Editor}

Silvia Marcia Russi de Domênico

Technical Support

Vitória Batista Santos Silva

\section{EDITORIAL PRODUCTION}

Publishing Coordination

Jéssica Dametta

Daniel de Almeida Leão
Language Editor

\section{Layout Designer \\ Emap}

Graphic Designer

Libro 